\title{
The effectiveness of google classroom in teaching English during Covid-19 at SMA N 1 M. Payed
}

\author{
Irma Dewi Isda ${ }^{1}$, Imran Imran ${ }^{2}$, Purwati Purwati ${ }^{3}$, Rahmiati Rahmiati ${ }^{4}$ \\ 1,2,3,4English Department, Faculty of Teachers and education, Universitas Samudra, Langsa, NAD \\ 1irmaisda.fkip@unsam.ac.id, ${ }^{2}$ imran@gmail.co.id, ${ }^{3}$ purwati@gmail.co.id, ${ }^{4}$ rahmiati@gmail.co.id \\ *) correspondence: irmaisda.fkip@unsam.ac.id
}

\begin{abstract}
This research aimed to find out Google Classroom effectiveness, which was used to enhance students' speaking skill. This research used a quasi-experimental with a pre-experimental research design. The subject of this study is the eleventh grade of senior high school at SMA N 1 M. Payed. It involved 25 students as a sample of this study. In the process of data collection, the researcher used a pre-test and post-test. The researcher analyzed the data using Wilcoxon Ranks Test to test the hypothesis. This study found the value of significance (2-tailed) was lower than the significance level $(0.000<0.05)$, then the Ha was accepted. It means there was a significant value on students' achievement of the speaking skill by using Google Classroom. Finding obtained of pretest 71,20 and posttest 78,16. In conclusion, the mean pretest and posttest scores differ significantly, or there is an effect of using google classroom enhancing students speaking skill at SMA N 1 Manyak Payed. However, it can be concluded that Google Classroom significantly affects students' speaking skill and helps them finish and collect the assignment without any bound by time and space.
\end{abstract}

Keywords: google classroom; teaching English; Covid-19

\section{INTRODUCTION}

Teaching and learning process are really important for students' exactly at the second grade of students in senior high school. They need the teacher to teach them about their teaching materials that related to their major, but since the beginning of march in 2020 the students cannot learn in the class their material like before because of the coronavirus or COVID-19. Coronavirus is a virus that attacks the respiratory system. It is due to infection with this virus and it is called COVID-19, coronavirus can cause mild disorders of the respiratory system, severe lung infection, and even death (Huang et al., 2019). Anyone can be infected with the corona virus like infants and young children, as well as people with weak immunity, are more vulnerable to this virus attack (Holshue et al., 2019). Coronavirus infection is caused by the coronavirus itself. Most coronaviruses spread like other viruses in general, such as Sprinkling saliva (swollen and sneezing), touch the hand or face of an infected person, touching the eyes, nose, or mouth after handling an item that is affected by saliva sprinkling with coronavirus. (yulandari.2020) Because this virus is really easy to spread from one person to another, the Government of the Republic of Indonesia has given a command to stop the teaching and learning process in every level of education in Indonesia especially in Aceh in order to minimize the people from infection of this virus. Although the government command is for the better for every people the students also got the disadvantages from this command. The students should study from home. How the way they can learn effective if they did not used technology. They can used technology to apply teaching learning process such as e-learning.

Rodrigues et al. (2019) defined e-learning as an innovative web-based system based on digital technologies and other forms of educational materials whose primary goal is to provide students with a personalized, learner-centered, open, enjoyable, and interactive learning environment supporting 
and enhancing the learning processes. Dawley (2007) found that e-learning encouraged learners to seek information, evaluate it, share it collaboratively and, ultimately, transform it into their own knowledge. It can be stated that e-learning as the technology that really influences for teaching learning process in searching educational material.

The world today has been getting into the new era called industry 4.0, in which all things are conducted by people using digital technology (Kerzik et al., 2018. It means that the industrial revolution 4.0 era, technological has important role in this country. No exception in the field of education. The younger generation is now more interested in learning using gadgets, smartphones, laptops, androids, and so on. They can easily open google search, you tube, google play store, etc., to access various kinds of information connected to the internet. Now days, be an English teacher should communicative and active in using teaching model. As we seen that teaching learning process easier to access through internet as online learning. It can be introduced with using google classroom as media in teaching learning process.

There are many embodiments of technology that can be applied in the education sector, such as Google Classroom, Zoom Cloud Meeting, and Duo lingo (Genova, 2019). Those are online applications that help teachers and students in learning. Google Classroom is an online application promoted by Google for schools intended to facilitate teachers in assorting, creating, and valuing the task in a paperless way (Negara, 2018). Zoom Cloud Meeting is a perfect tool for those who are on the way and still need to have a meeting. It has a special group service of massages in the real-time and secure recording sessions (Archibald, Ambagtsheer, Casey, \& Lawless, 2019). Duo lingo is a useful language application that gives learners the systematic and practical steps to know a new language independently.

Based on the preliminary of this research, the researcher done the observation to the SMA N 1 Manyak Payed Aceh Tamiang, the process of teaching learning English at that school not running well as the pandemi. They should learn from home using their mobile phone. So, the teacher should think harder to overcome this situation. As we know that google classroom is easier media to teach them and can be used as an alternative to train students' especially in speaking where they can change their smartphones by learning anytime and anywhere by looking at video speaking shared by the teacher. With google classroom the teacher uses computer technology with internet access to provide information, reading material, videos and learning materials for students. Related to those condition, students can learn best when they have attractive model in the teaching learning process.

In fact, Teaching speaking through google classroom can be very useful for the effective and joyful learning. the researcher aims to find out "The effectiveness of google classroom in teaching speaking skill at SMA N 1 Manyak Payed Aceh Tamiang". Based on the background above, two research questions were formulated to this study, both are; Is there an effect of google classroom on the English-speaking skills at SMA N 1 M. Payed Aceh Tamiang? And Are there differences in the level of English-speaking skills of SMA N 1 M. Payed students at Aceh Tamiang, before and after used google classroom as media in teaching learning process.

\section{Speaking}

Speaking is the ability to communicate in issuing ideas and messages orally. The ability of students to communicate requires language delivery in real communication.

Based on Gert and Hans (2008: 207), speaking is the ability to speak or utterance that has a specific purpose and purpose that is known to the speaker and listener. Hafizah (in the 2016 pandapotan) stated that so far teaching the skills of speaking and listening (especially speaking) has not gotten the maximum results as expected. The students did not fully have the communicative skills. They are still afraid, ashamed, and hesitant when it comes to speaking in public and conveying their ideas.

The speaking learning material to be taught in school is speaking activities without speaking theories. Kundharu Saddhono and St. Y. Slamet (2012: 59) notes that the speaking learning material listed in the curriculum includes activities, (1) lecturing, (2) debating, (3) conversing, (4) preaching, (5) telephone, (6) telling stories, (7) giving speeches, (8) exchanging ideas, (9) asking questions, (10) playing roles, (11) interviewing, (12) discussing, (13) campaigning, (14) delivering remarks, 


\section{Benny Kurnianto}

congratulations, messages, (15) reporting, (16) responding, (17) refuting opinions, (18) rejecting requests, offers, invitations, (19) answering questions, (20) expressing attitudes, (21) informing, (22) speaking, (23) describe the contents of the drama, (24) describe how to make something, (25) offer something, (26) apologize, (27) give directions, (28) introduce oneself, (29) greet, (30) invite, (31) invite , (32) warned, (33) corrected, and (34) question and answer.

Tarigan in isnani 2013 speaking is the ability to pronounce articulated sounds or words to express, express or convey thoughts, ideas and feelings. Speaking is also defined as a tool for communicating ideas that are structured and developed according to needs. Talking basically has a general purpose to convey. There are three general purposes in speaking, namely: (a) inform and report (toinform), (b) entertain and entertain (to entertain), and (c) persuade, invite, urge, and convincing (to persuade) (Henry Guntur Tarigan, 2008: 16-17).

According to Mudini Salamat Purba (2009: 4-5), in general the objectives of the conversation are: (1) encouraging or stimulating, (2) convincing, (3) moving, (4) informing, and (5) entertaining. The following are steps that must be mastered by a good speaker, namely: (a) selecting topics, speaker interests, speaking skills, listener interests, listening skills, time provided, (b) understanding and testing topics, understanding listeners, situations, the listener's background, level of ability, facilities, and (c) formulating the framework of the conversation, introduction, content and closing (Kundharu Saddhono and Slamet, 2012: 6)

\section{Google Classroom}

Google Classroom is considered one of Google's web's best features for improving teachers' and students' performance in teaching and learning activities. (Nurlaili 2020) it can be stated as one place to share all activities in teaching learning process. Iftakhar,2016 (stated in nur laili 2020) explained that Google Classroom is the best feature provided by the Google platform that can be used by the scholar to get information about the class material with the use of many times saved. It means we can access and save the material whenever and wherever, no limitation time.

Nur laili (2020) stated Google Classroom is completely simple to be used. Here are all available features integrated and correlated between one and others. The teachers facilitated to keep all files in Google Drive. Using this device, they can give rank and level, attach pdf, photo, video, voice note, document, or any links for instructional purposes. From Google Classroom, the teacher can send the assignment to all learners' at the same time and more focused on explaining the material during the class (Iftakhar, 2016 in nur laili 2020). It means Google classroom is effective flatform to teach speaking because we can share the materials like file, video that's connect to you tube, ppt, pdf and we can do the assignment, quiz at that flatform but there is one disadvantage we can not make direct interaction as face to face with our students like zoom.

\section{METHODS}

This research refers to a quantitative research approach. According to Nana S. Sukmadinata (2010), quantitative research is based on the philosophy of positivism which emphasizes objective phenomena that are studied quantitatively or carried out using numbers, statistical processing, structure, and controlled experiments. While the type of research used in this study is a quasi-experimental design research. Sugiyono (2007) defines that experimental research is research that is used to find the effect of certain treatments on others under controlled conditions

This research uses quasi-experimental (quasi-experimental). The design of this study is a preexperimental design (Non design) by one group pretest post-test design. The dependent variable of this study is the blended learning model, while the independent variable is speaking skills. The instrument used was an oral test with a Likert scale of 0-4. The students' scores of speaking in the pretest and post-test were compared for both groups in order to determine whether there were significant differences between the groups in relation to the treatment. 
TABLE 1. Research Design

\begin{tabular}{ccc}
\hline Pretest & Experiment & Posttest \\
\hline $\mathrm{O} 1$ & $\mathrm{X} 1$ & $\mathrm{O} 2$ \\
\hline
\end{tabular}

Information:

$\mathrm{X} 1=$ Using the Blended learning

$\mathrm{O} 1=$ Pretest Observation in model class before Blended Learning

$\mathrm{O} 2=$ Posttest observation in the model class after Blended Learning

The populations of this study were the students of SMA N 1 Manyak Payed. The sample was used eleven grade students. The Total of students as many as 25 students of eleven class. The research sample was selected based on purposive sampling technique.

The instruments used in this study were observation and test. The observation guidelines used in this study are the observation guidelines made by students during the learning of speaking skills using google classroom. At the test researcher used instrument for recording the students' performances during the action given, such as talk about offering/ suggestion, giving opinion and inviting someone. There were two kinds of test used in this research, such as pre-test (test 1) for the preliminary observation in speaking, post-test (test 2) after the treatment for the final performance in speaking. The speaking tests in pre-test and post-test were scored based on oral proficiency scoring categories (Brown and Abeywickrama, 2004). The description of the students' speaking scores was a modified form of scale 0-100 which included five speaking components, namely grammar, vocabulary, comprehension, fluency, and pronunciation.

TABLE 1. The criterion of speaking scores

\begin{tabular}{lll}
\hline No & The Indicator of Assessments & Scores \\
\hline 1 & Grammar & $0-4$ \\
\hline 2 & Vocabulary & $0-4$ \\
\hline 3 & Comprehension & $0-4$ \\
\hline 4 & Fluency & $0-4$ \\
\hline 5 & Pronunciation & $0-4$ \\
\hline
\end{tabular}

\section{RESULTS AND DISCUSSION}

Before the testing of hypothesis using the $t$ test, the result of data about the effectiveness of google classroom in teaching speaking skill at SMA N 1 Manyak Payed Aceh Tamiang especially the test data normality as a t-test requirement. Based on the normality test the data was obtained that the data on student learning outcomes students speaking skill using Google Classroom distributed media with unnormal (Table 2).

This is shown from test results using the Kolmogorov-Smirnov where Sig of pretest $(0.327)>$ $\alpha,(0.05)$ distributed with normal but sig in posttest $(0,013)<\alpha(0,05)$ not distributed with normal, that is why the researcher cannot used t-test but used Wilcoxon test.

TABLE 2. Test of Normality

\begin{tabular}{|c|c|c|c|c|c|c|c|}
\hline \multicolumn{3}{|c|}{ Kolmogorov - Smirnov } & \multicolumn{5}{|c|}{ Shapiro- Wilk } \\
\hline & Statistic & Df & Sig & Statistic & Df & & Sig \\
\hline Pretest & ,147 & 25 & ,170 & ,955 & & 25 & ,327 \\
\hline Posttest &, 236 & 25 &, 001 & ,894 & & 25 & ,013 \\
\hline
\end{tabular}




\section{Benny Kurnianto}

TABEL 3. Paired Sampel Statistic dan Corelation

\begin{tabular}{lcccc}
\hline Experiment & Mean & N & Std. Deviation & Sig \\
\hline Pre-test & 71,20 & 25 & 3,697 &, 327 \\
\hline Post-test & 78,16 & 25 & 2,672 &, 013 \\
\hline
\end{tabular}

TABLE 4. Wilcoxon Signed Ranks Test

\begin{tabular}{|c|c|}
\hline & Post test-Pretest \\
\hline $\mathrm{Z}$ & $-4.377^{\mathrm{b}}$ \\
\hline Asymp. Sig. (2-tailed) & .000 \\
\hline
\end{tabular}

Table 4, shown that sig. 2-tailed $=0.000<\alpha(0.05)$, it means reject H0. In conclusion, the mean pretest and posttest scores differ significantly, or there is an effectiveness of using google classroom in teaching students speaking skill of SMA N 1 M. Payed.

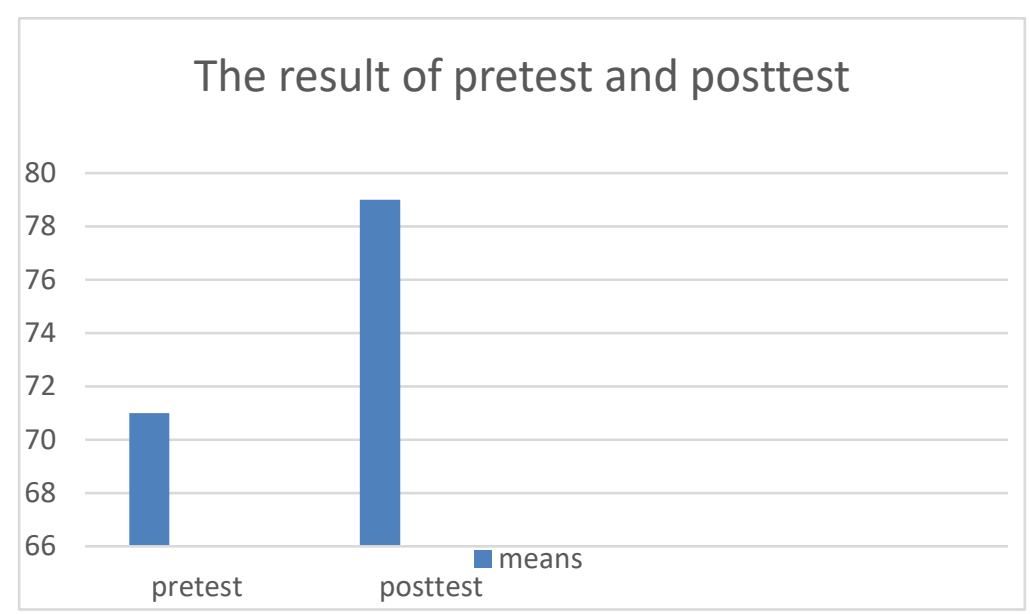

FIGURE 1. the result of pretest and posttest

The figure 1, shown that the mean score in pretest is lower than in the post-test. However, it can be concluded that there were highly significant differences between teaching not using google classroom and using google classroom media. The application of this learning is in line with the philosophical essence of e-learning that e-learning itself doesn't mean to replace totally the conventional learning model in the class, but it can strengthen the model of learning through diversifying the learning content and utilizing the educational technology.Based on the results of data analysis shown that there was a significant enhancement of speaking skill between pretest and posttest using the Google Classroom media in enhancing students speaking skill. The differences of pretest 71,20 and posttest 78,16.

Based on the result of the preliminary observation, the researcher was started for the next instruction by applying the treatment. In the planning step the researcher concerned on enhance the students' speaking skill on the English subject through google classroom in the experimental group.

The teacher used three topics in teaching learning, that titles are offering something, giving opinion and inviting someone. The researcher chooses that topic based on appropriate curriculum from eleven grade students with seeing the syllabus at that class. At the first online meeting, the teacher posted material about offering something. At that google classroom the teacher sent her video recording about material explanation and give them ppt as adding source. After that the teacher make discussion via comment column, the students can ask anything related the material at the column.

At the second online meeting, the teacher posted material about giving opinion. She used video recording to record the material, she explained about how to create conversation using that expressions than sent the explanation about giving the opinion via YouTube channel to the students, after that the teacher open the session of asking and answering question related to the topic at the 
comment column, than the teacher ask the students to create the conversation related to the topics that already given.

At the third online meeting, the teacher posted the material of how to invite someone, she explained the kinds of expression used at the dialog, then shared video from the native that attached from YouTube to google classroom. The students really interested followed the class it can be proved by their assignment at the video recording, any improvement at the vocabulary, grammar, performance, pronunciation, intention and fluency. It can be seen based on the posttest given by the teacher at the last online meeting using google classroom media.

From the result of the pre-test to the result of the post-test after the treatment using google classroom, it showed rather an effectiveness. This significant difference between the students' speaking skill in the pre-test and post-test is the effectiveness using google classroom in teaching speaking. By using google classroom platform the students easier to understand the explanation because they learned speaking by some expert video. The teacher sent all of the material as file, ppt and video from youtube. They can access whenever and wherever.

Based on this study's results in the previous section, the table of Wilcoxon Signed Ranks Test statistics showed the significance level was 0.000 . As a hypothesis requirement, when the significance level smaller than significance (0.05), which indicates that the null hypothesis (Ho) is rejected and the alternative hypothesis $(\mathrm{Ha})$ is accepted. In contrast, if the significance value is higher than (0.05), it indicates that the null hypothesis ( $\mathrm{Ho})$ is accepted, and the alternative hypothesis $(\mathrm{Ha})$ is rejected. Based on the statement above, it can be inferred that the alternative hypothesis ( $\mathrm{Ha}$ ) was accepted, while the null hypothesis (Ho) was rejected based on the result of the significant value $0.000<0.05$.

This study's result was in line with (Negara 2018 in nurlaili 2020) that Google Classroom is an online medium generated to help teachers or lecturers create a task, share teaching material, collect paperless assignments, assess student duty, and be attributed by automatic document storage. It can be stated as awesome media that completely available in teaching learning process because so many items paperless we can share at that platform.

\section{CONCLUSION}

Based on the result of the findings and discussion stated earlier, it can be concluded that the effectiveness of google classroom in teaching English during covid 19 especially in speaking skill at SMA N 1 Manyak Payed differ significantly or there is an effect of google classroom on enhancing students speaking skill at that school. It can be shown that there was a significant enhancement of speaking skill between pretest and posttest using Google Classroom media in enhancing students speaking skill. The differences of pretest 71,20 and posttest 78,16 . Considering the conclusion formulated above, google classroom can be used as an alternative model or activities in English class.

The implementation of Google Classroom as a medium in teaching speaking has a significant effect on the students' in speaking english. In other words, Google Classroom also assists teachers and students in communicating the material and assignment between them. Furthermore, it might need more time, more effort, and more spirit for teachers and additional techniques to enhance students' speaking skill.

\section{ACKNOWLEDGEMENTS}

The researcher realized that the accomplishment of this article would not run well without any help from the others. Therefore, here she wishes to give her sincerest gratitude and appreciation to her dean and colleagues who have support and valuable comments in any part of this manuscript. Finally, this article is still far from being perfect. Hence, any criticisms or suggestions from the readers and users are welcome to the researcher in order to make improvement. In the same time, the researcher hopes that this article can be useful for other writers, teachers, and students. 


\section{Benny Kurnianto}

\section{REFERENCES}

Brown, H. D., \& Abeywickrama, P. (2004). Language assessment. Principles and Classroom Practices. White Plains, NY: Pearson Education

Carman, J. M. (2005). Blended Learning Design: Five Key Ingredients. Blended Learning Design: 5 Key Ingredients. https://doi.org/10.1109/CSSE.2008.198

Dawley, L. (2007) The tools for successful online teaching, London: Information Science Publishing. Hengki, T, P (2014). Implementasi Model Pembelajaran Blended Learning Untuk Meningkatkan Aktifitas Belajar Multimedia Siswa Kelas XI Multimedia 1 SMK Mubammadiah 2 Klaten Utara Tabun Ajaran 2013/2014. Yogyakarta (ID): UNY

Ginaya. G, Rezeki. M, Astuti.S (2018). The Effects of Blended Learning to Students' Speaking Ability: A Study of Utilizing Technology to Strengthen the Conventional Instruction. IJLLC (International Journal of Linguistics, Literature and Culture),4(3), 1-14. http://dx.doi.org/10.21744/ijllc.v0i0.000

Garrison, D. R. (2011). E-learning in the 21st century: A framework for research and practice. Taylor \& Francis.

Maryam. S, (2020). Utilizing Communicative Language Games to Improve Students' Speaking Ability. JOLLT (Journal of Languages and Language Teaching), 8(3), 251-263. http://ojs.ikipmataram.ac.id/index.php/jollt/index

Masie, E. (2002) Blended learning: the magic is in the mix, The ASTD e-learning handbook, New York: Mc Graw-Hill.

Ni'matul Qariah, Munoto \& Lilik A (2017). Pengaruh Model Pembelajaran Blended Learning Dan Motivasi Belajar Terhadap Hasil Belajar Siswa. Jurnal Penelitian Ilmu Pendidikan. 2(10),97-110

Nurlaili, E. Muflihah T. (2020). The Effectiveness of google classroom in teaching writing or recount text for senior high schools. JOLLT Journal of Languages and Language Teaching.4(8),348359

Pramila, K \& Thomas, J (2019). Impact of Blended Learning on the Speaking Skills of English as a Foreign Language (EFL) Learners at Sohar University. Anthropologist, 35(1-3), 47-56. http://DOI: 10.31901/24566802.2019/35.1-3.2039

Sarah, B (2015). Efektivitas Model Blended Learning Terhadap Motivasi Dan Tingkat Pemahaman Mahasiswa Mata Kuliah Algoritma Dan Pemrograman. Jurnal Pendidikan Vocasi.1(5),74-87

Setyoko, Indriaty (2018). Implementasi Pembelajaran Blended Learning Berbasis Media Google Classrom Terhadap Hasil Belajar Mahasiswa Pendidikan Fisika. JPFS (Jurnal Pendidikan Fisika dan Sains Universitas Samudra). 1(1), 5-10

Sofiana, N (2015). Implementasi Blended Learning Pada Mata Kuliah Extensive Listening. Jurnal Tarbawi.1(12), 59-70.

Suryaningsih. 2017. Pengarub Metode Pembelajaran Show and Tell Terbadap Keterampilan Berbicara Siswa Kelas IV Tema 6 Daerah Tempat TinggalKu Di SD Muhammadiah Condongcatur. Yogyakarta (ID): UIN Sunankalijaga Yogyakarta.

Yulandari Safitri, E (2020). English Students' Perception about Daring Learning while Quarantine: a Qualitative Case Study. JOLLT Journal of Languages and Language Teaching. 3(8),312-322

Wahyuni. S, Elfita F. (2018). Pengaruh Blended Learning Model dan Sikap Berbahasa Terhadap Kemampuan Menulis Bahasa Inggris Siswa Sekolah Menengah Negeri di Pekan Baru. Jurnal GERAM.1(6),1-9 